\title{
Raised serum copper and caeruloplasmin levels in subjects taking oral contraceptives
}

\author{
M. E. CARRUTHERS, C. B. HOBBS, AND R. L. WARREN \\ From the Courtauld Institute of Biochemistry, The Middlesex Hospital Medical School, \\ London
}

SYNOPSIS A marked increase in the serum copper and caeruloplasmin levels in 25 female subjects taking oral contraceptives is noted.

The correlation between the copper and caeruloplasmin concentrations, together with the finding of normal urine copper levels in 10 of the subjects, suggests that the increased serum copper is due to increased caeruloplasmin synthesis.

During the course of establishing a normal range for serum copper concentration by flame spectrophotometry, occasional anomalously high values were encountered and it was subsequently found that these results could be related to the ingestion of oral contraceptives. The present survey was undertaken to investigate the effect of these preparations on the levels of the total serum copper and caeruloplasmin. The purpose of this communication is to point out that the serum copper and caeruloplasmin concentrations were consistently increased in the subjects taking oral contraceptive preparations.

\section{SUBJECTS AND METHODS}

The concentrations of serum copper and caeruloplasmin were measured in a control group of 23 healthy ambulant females between the ages of 18 and 45 years (mean $25 \cdot 7$ years), and in a test group of 25 healthy, ambulant, female subjects whose age range was also 18 to 45 years (mean 28.3 years), who were taking oral contraceptives.

Urine copper was determined in 10 random samples from separate individuals in the test group.

The type of oral contraceptive preparation and the period for which it had been taken is shown in Table I, which also indicates the day of the cycle on which the blood sample was taken.

No subject in either group was taking any other steroid.

Blood samples were collected into plastic tubes using plastic disposable syringes. Serum and urine copper levels were determined by high-resolution flame spectrophotometry (Warren, 1965). Serum caeruloplasmin was assayed using the method of Houchin (1958).

In order to exclude any cases of possible liver damage the L-aspartate:2-oxoglutarate aminotransferase (EC 2.6.1.1.) and the L-alanine:2-oxoglutarate aminotransferase (EC 2.6.1.2.) were measured in the test group Received for publication 15 March 1966. using the colorimetric procedure of Reitman and Frankel (1957).

An indication of the relative oestrogenic activities of the different preparations taken by the test group of subjects was obtained from vaginal smears. These were stained by the Papanicolaou method and the karyopyknotic indices determined according to the criteria of Wachtel (1964).

In three cases blood samples were obtained before and during medication.

\section{RESULTS}

CONTROL GROUP The range of serum copper concentrations obtained was $95-140 \mu \mathrm{g}$. $/ 100 \mathrm{ml}$. with a mean of $121 \mu \mathrm{g} . / 100 \mathrm{ml}$. Standard deviation was 11.4. The caeruloplasmin levels varied from $19 \cdot 5$ to $38.2 \mathrm{mg} . / 100 \mathrm{ml}$. with a mean of $31.2 \mathrm{mg}$. $/ 100 \mathrm{ml}$. Standard deviation was $5 \cdot 7$.

TEST GROUP The serum levels of copper and caeruloplasmin, together with the karyopyknotic indices, are presented in Table I.

The mean serum copper level in this group was $258.4 \mu \mathrm{g} . / 100 \mathrm{ml}$. and the mean caeruloplasmin level was $80.3 \mathrm{mg} . / 100 \mathrm{ml}$. The serum copper and caeruloplasmin levels in the three subjects before and during medication are shown in Table II.

The urine copper concentrations in the random samples from 10 subjects in the test group were all less than $0.1 \mathrm{mg}$./litre. All the aminotransferase assays gave results within the normal range.

\section{DISCUSSION}

It has been reported on many occasions that the serum copper concentration is increased in the last 
TABLE I

DETAILS OF 25 WOMEN TAKING ORAL CONTRACEPTIVES

\begin{tabular}{|c|c|c|c|c|c|c|c|}
\hline Subject & Age & $\begin{array}{l}\text { Day of } \\
\text { Cycle }\end{array}$ & $\begin{array}{l}\text { Duration of } \\
\text { Medication } \\
\text { (Mth.) }\end{array}$ & $\begin{array}{l}\text { Karyopyknotic } \\
\text { Index } \\
(\%)\end{array}$ & $\begin{array}{l}\text { Serum } \\
\text { Caeruloplasmin } \\
(\mathrm{mg} . / 100 \mathrm{ml} .)\end{array}$ & $\begin{array}{l}\text { Serum } \\
\text { Copper } \\
(\mu \mathrm{g} . / 100 \mathrm{ml} .)\end{array}$ & $\begin{array}{l}\text { Direct Reacting } \\
\text { Copper } \\
(\mu \mathrm{g} . / 100 \mathrm{ml} .)\end{array}$ \\
\hline \multicolumn{8}{|c|}{ Feminor Sequential (mestranol $0.1 \mathrm{mg}$. days 5 to 19 and norethynodrel $5 \mathrm{mg}$. + mestranol $0.075 \mathrm{mg}$. days 20 to 24. ) } \\
\hline 1 & 43 & 7 & 12 & 2 & 99 & 295 & 31 \\
\hline 2 & 32 & 8 & 24 & 15 & 85 & 260 & 30 \\
\hline 3 & 22 & 8 & 6 & 26 & 84 & 290 & 35 \\
\hline 4 & 23 & 16 & 10 & 53 & 103 & 325 & 35 \\
\hline 5 & 25 & 18 & 18 & 66 & 98 & 260 & 一 \\
\hline 6 & 19 & 21 & 1 & 11 & 77 & 250 & - \\
\hline 7 & 22 & 21 & 30 & 15 & 85 & 265 & - \\
\hline 8 & 23 & 21 & 24 & 33 & 100 & 335 & - \\
\hline 9 & 29 & 21 & 47 & 34 & 78 & 235 & 40 \\
\hline 10 & 24 & 22 & 28 & 59 & 68 & 180 & - \\
\hline 11 & 45 & 27 & 3 & 15 & 96 & 305 & 40 \\
\hline 12 & 18 & 28 & 1 & - & 76 & 310 & - \\
\hline \multicolumn{8}{|c|}{ Conovid $E$ (norethynodrel $2.5 \mathrm{mg}$. + mestranol $0.1 \mathrm{mg}$. days 5 to 24 ) } \\
\hline 13 & 39 & 18 & 24 & 30 & 99 & 305 & - \\
\hline 14 & 35 & 20 & 33 & 43 & 60 & 225 & - \\
\hline \multicolumn{8}{|c|}{ Lyndiol (lynoestrol $5 \mathrm{mg}$. + mestranol $0.15 \mathrm{mg}$. days 5 to 24) } \\
\hline 15 & 27 & 6 & 12 & - & 73 & 230 & 一 \\
\hline \multicolumn{8}{|c|}{ Norlestrin (norethisterone acetate $2.5 \mathrm{mg}$. + ethinyl oestradiol $0.05 \mathrm{mg}$. days 5 to 24) } \\
\hline 16 & 34 & 12 & 18 & 2 & 60 & 215 & - \\
\hline 17 & & 12 & 2 & 1 & 57 & 185 & - \\
\hline 18 & 22 & 13 & $1 \overline{2}$ & 5 & 56 & 185 & - \\
\hline 19 & 27 & 13 & 2 & 4 & 68 & 270 & 22 \\
\hline 20 & 31 & 20 & 2 & 8 & 78 & 290 & 33 \\
\hline \multicolumn{8}{|c|}{ Ovulen (ethynodiol diacetate $1 \mathrm{mg}$. + mestranol $0.1 \mathrm{mg}$. days 5 to 24) } \\
\hline 21 & 23 & 17 & 48 & 42 & 70 & 225 & 22 \\
\hline 22 & 43 & 20 & 24 & 8 & 112 & 285 & 29 \\
\hline 23 & 21 & 24 & 1 & 7 & 62 & 275 & 30 \\
\hline 24 & 33 & 25 & 30 & 9 & 90 & 240 & - \\
\hline \multicolumn{8}{|c|}{ Anovlar (norethisterone acetate $4 \mathrm{mg}$. + ethinyl oestradiol $0.05 \mathrm{mg}$. days 5 to 24) } \\
\hline 25 & 23 & 25 & 36 & 1 & 73 & 220 & 33 \\
\hline \multicolumn{8}{|c|}{${ }^{1}$ Gubler, Lahey, Cartwright, and Wintrobe (1953). } \\
\hline \multicolumn{8}{|c|}{ TABLE II } \\
\hline \multicolumn{8}{|c|}{ SERUM COPPER AND CAERULOPLASMIN LEVELS BEFORE AND DURING MEDICATION WITH ORAL CONTRACEPTIVES } \\
\hline \multirow[t]{2}{*}{ Age } & \multirow{2}{*}{\multicolumn{2}{|c|}{ Preparation }} & \multirow{2}{*}{$\begin{array}{l}\text { Duration of } \\
\text { Medication } \\
\text { (days) }\end{array}$} & \multicolumn{2}{|c|}{$\begin{array}{l}\text { Serum Caeruloplasmin } \\
(\mathrm{mg} . / 100 \mathrm{ml} .)\end{array}$} & \multicolumn{2}{|l|}{$\begin{array}{l}\text { Serum Copper } \\
(\mu \mathrm{g} . / 100 \mathrm{ml} .)\end{array}$} \\
\hline & & & & Before & During & Before & During \\
\hline $\begin{array}{l}18 \\
19 \\
21\end{array}$ & $\begin{array}{l}\text { Fem } \\
\text { Fem } \\
\text { Ovu }\end{array}$ & $\begin{array}{l}\text { tial } \\
\text { tial }\end{array}$ & $\begin{array}{l}22 \\
17 \\
18\end{array}$ & $\begin{array}{l}34 \cdot 3 \\
37 \cdot 3 \\
30 \cdot 5\end{array}$ & $\begin{array}{l}76 \\
77 \\
62\end{array}$ & $\begin{array}{l}125 \\
125 \\
125\end{array}$ & $\begin{array}{l}310 \\
250 \\
275\end{array}$ \\
\hline
\end{tabular}

trimester of pregnancy (Thompson and Watson, 1949; Cartwright, 1950; Lahey, Gubler, Cartwright, and Wintrobe, 1953; Markowitz, Gubler, Mahoney, Cartwright, and Wintrobe, 1955). Von Studnitz and Berezin (1958) suggested that this elevation of the serum copper level was due to the action of endogenous oestrogen, and in support quoted the earlier work of Turpin, Schmitt-Jubeau, and Jérome (1950), Elsner and Hornkiewicz (1954), and Russ and Raymunt (1956), who observed a marked elevation of the serum copper following the administration of oestrogens to human subjects. More recently Gault, Stein, and Aronoff (1966) have reported increased caeruloplasmin levels in four subjects taking oestrogens.

It is therefore not surprising, in view of the oestrogen content of these preparations (see Table I), that the most notable feature of the results is the marked elevation of the serum copper and caeruloplasmin levels in the test group. In no case was the serum copper or caeruloplasmin level within the normal range, the lowest copper level in the subjects taking these preparations being $180 \mu \mathrm{g} . / 100 \mathrm{ml}$.

Although no attempt was made to collect samples on a specific day of the menstrual cycle the $\pm 15 \%$ variation of serum copper reported to occur during 


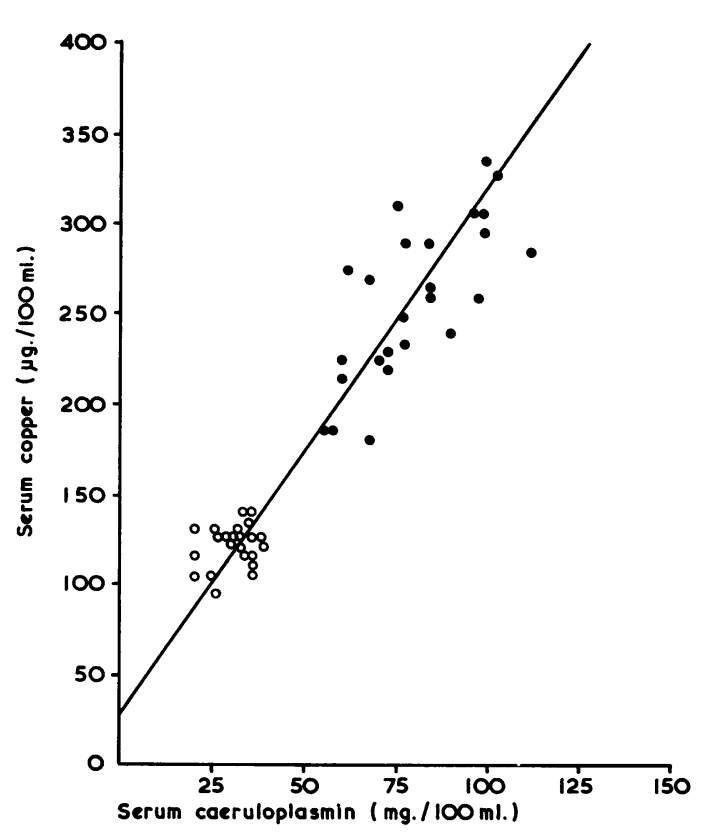

FIG. 1. Relationship between serum copper and caeruloplasmin levels. Open circles (-O-) represent the control group, and closed circles (- - ) the test group.

the cycle (von Studnitz and Berezin, 1958) is small compared with the increase in serum copper seen in the test subjects.

Figure 1 shows the serum copper concentration plotted against the corresponding caeruloplasmin level for each sample in the control and test groups. The calculated regression line is also shown. The coefficient of correlation of the serum copper and caeruloplasmin concentrations is 0.94 . This high degree of correlation is consistent with the theory that the increased serum copper concentration is due to increased synthesis of caeruloplasmin. Furthermore the finding of urine copper concentrations of less than $0.1 \mathrm{mg}$./litre in 10 random samples taken from separate individuals within the group taking oral contraceptives supports this view in so far as it suggests that the additional copper in the serum is firmly bound to protein and is therefore not excreted in the urine.

We wish to thank Professor R. H. S. Thompson for his advice; Dr. G. Barry Carruthers for sending us blood and urine samples from his patients; and our friends who volunteered as 'normal' subjects.

\section{REFERENCES}

Cartwright, G. E. (1950). In Copper Metabolism, edited by W. D. McElroy and B. Glass, p. 274. The John Hopkins Press, Baltimore.

Elsner, P., and Hornykiewicz, O. (1954). Arch. Gynäk., 185, 251.

Gault, M. H., Stein, J., and Aronoff, A. (1966). Gastroenterology, 50, 8.

Gubler, C. J., Lahey, M. E., Cartwright, G. E., and Wintrobe, M. M. (1953). J. clin. Invest., 32, 405.

Houchin, O. B. (1958). Clin. Chem., 4, 519.

Lahey, M. E., Gubler, C. J., Cartwright, G. E., and Wintrobe, M. M. (1953). J. clin. Invest., 32, 329.

Markowitz, H., Gubler, C. J., Mahoney, J. P., Cartwright, G. E., and Wintrobe, M. M. (1955). Ibid., 34, 1498.

Reitman, S., and Frankel, S. (1957). Amer. J. clin. Path., 28, 56.

Russ, E. M., and Raymunt, J. (1956). Proc. Soc. exp. Biol. (N.Y.), $92,465$.

Studnitz, W. von. and Berezin, D. (1958). Acta endocr. (Kbh.), 27, 245.

Thompson, R. H. S., and Watson, D. (1949). J. clin. Path., 2, 193. Turpin, R., Schmitt-Jubeau, H., and Jérome, H. (1950). C. R. Soc. Biol. (Paris), 144, 352.

Wachtel, E. G. (1964). Exfoliative Cytology in Gynaecological Practice. Butterworth, London.

Warren, R. L. (1965). Analyst, 90, 549. 